\title{
THE MAIN THEORETICAL ASPECTS OF SYSTEM OF CRISIS MANAGEMENT AT THE ENTERPRISE
}

\section{Chupryna Natalia ${ }^{1}$ \\ Haievskyi Vladyslav ${ }^{2}$ \\ DOI: http://dx.doi.org/10.30525/978-9934-571-28-2_27}

\begin{abstract}
In national economy more and more attention is paid to research of effective ways of elimination of crisis situations. This situation which has arisen for today's period in domestic economy leads to active development of the crisis phenomena both on macro- and at the micro level, having carried out the activity analysis of business subjects, becomes obvious that many enterprises works is unprofitable, the amount of bankruptcies increases. All these questions demand from the enterprises to use those tools which will help to overcome the crisis phenomena in the activity and not to allow further bankruptcy of these enterprises. It has given an impetus for development and research of rather new type of management, it is anti-recessionary. A research object of this article is the analysis and the choice of the best management crisis methods by the enterprise.

Relevance research of crisis management for the Ukrainian enterprises demands a certain method by which it is possible to decide what methods will be necessary to a certain enterprise for an exit from a crisis.

The purpose of this article is studying of theoretical approaches to research of the concept "crisis management by the enterprise", consideration of the main problems of efficiency's crisis management by the subject of any business and lighting of the main instruments of crisis management by the enterprise.

Each enterprise has to carry out constantly monitoring as on a certain segment of the market where it conducts the direct activity, and to carry out introspection for prevention's emergence of the crisis phenomena. Enough
\end{abstract}

\footnotetext{
${ }^{1}$ Candidate of Economic Sciences. Associate Professor,

Dean of the Faculty of Economics,

Ukrainian State University of Chemical Technology, Ukraine

${ }^{2}$ Postgraduate Student of the Department of Marketing,

Ukrainian State University of Chemical Technology, Ukraine
} 
attention was paid to research of a question of crisis management. But, having conducted researches of methods' crisis management known for today omit at this stage of economy development for the domestic enterprises such method of crisis management as a benchmarking will be the best. For this reason the administrative board of any enterprise has to realize a role of system's crisis management at the enterprise as constantly existing subsystem.

\section{Introduction}

In national economy throughout the last period more and more attention is paid to research of a question of opportunities of an economic crisis and effective ways of her elimination. This situation which has arisen for today's period leads to active development of the crisis phenomena both at the macro level, and at the micro level as, having carried out the analysis of activity of subjects of any business, becomes obvious that many enterprises works is unprofitable, the amount of bankruptcies increases, grows creditor and debit debts. All these questions demand from the enterprises to use those tools which will help to increase efficiency of their current activity in the activity, to overcome the crisis phenomena and not to allow further bankruptcy of these enterprises. Therefore, before many owners of subjects of business there was a key question: "It is worth operating a subject of business which at this stage is on the verge of bankruptcy and whether it is necessary to do it in general?" It has given an impetus for development and research of rather new type of management - anti-recessionary which allows investigating the crisis phenomena during the certain period, to take certain measures for overcoming bankruptcy and development of this strategy which will allow not to allow creations of new crisis factors which will have much influence on financial economic activity of the enterprise.

Now many scientists-economists paid to a question of research of crisis management and its development attention. The big contribution to development of this research was lit in the works by an amount foreign and domestic scientists, namely: E. Altman, R. Keller, I. Ansoff, T. Taffler, A. Bolshakov, M. Pashuta, T. V. Bulovich, S. V. Kudlayenko, A. M. Tkachenko, A. V. Mikhaylenko, V. V. Kovalenko, M. V. Suganyaka, V. I. Fuchedzhi, A. A. Tereshchenko, V. A. Vasilenko, P. Ivanov, V. I. Koshkin, A. Galchinsky, V. Geyts, I. Zyatkovsky, M. Bilyk, V. Biver, 
J. Akerlof, R. Coase, K. Errou, M. Spens, J. U. Sharp, J. Schumpeter, P. Uotermen, A. Smith, E. M. Korotkov, Koretsky S. L., G. Birman, G. Brele, J. Finnera, S. Schmidt, R. lust, Gasanov S. S., Arefyev A. V., Koltsov, D. A. Ryabykh. However, despite a huge number of works in this direction of a research of an above-mentioned question, the research of a problem of crisis management and its main tools demands a further research. It can be explained with an economic and political crisis, development of economy of the state in general, well, and, of course, absence effective the institutional environment.

The purpose of this article is studying of theoretical approaches to research of the concept "crisis management by the enterprise", consideration of the main problems of efficiency of crisis management by the subject of any business and lighting of the main instruments of crisis management by the enterprise.

\section{Determination of class "crisis management" and its components}

Today it is possible to find the most various concepts of economic class "crisis management" in scientific literature. This economic class I have stayed it is widespread in many branches, such as: the right, law, economy, and marketing and is a lot of other social sciences. The research of the essence of crisis management usually consists in studying of his characteristic, certain features, tools, mechanisms and elements of process of crisis management.

We have tried to generalize the analysis of research of an interpretation of an essence of economic class "crisis management", is carried out by outstanding scientists-economists and to say it by means of the table.

\begin{tabular}{|l|l|}
\hline \multicolumn{1}{|c|}{ Author } & \multicolumn{1}{c|}{ Definition of the concept "crisis management" } \\
\hline Tulenkov N. V. & Any management of the organization has to be anti-recessionary \\
\hline $\begin{array}{l}\text { Minaeva E.S., } \\
\text { Panagushena V.P. }\end{array}$ & $\begin{array}{l}\text { Crisis management is not only the management focused on a } \\
\text { conclusion of the enterprise from a condition of crisis, and man- } \\
\text { agement which is capable to predict and prevent insolvency of } \\
\text { the enterprise according to the developed strategic program of } \\
\text { increase in competitive advantages and financial improvement } \\
\text { in advance. }\end{array}$ \\
\hline Meskon M. & $\begin{array}{l}\text { As the process of planning, the organization, motivation and } \\
\text { control necessary to formulate and make the goal facing the } \\
\text { organization. }\end{array}$ \\
\hline
\end{tabular}


The main theoretical aspects of system of crisis management at the...

Continuation of Table

\begin{tabular}{|c|c|}
\hline Ligonenko L.O. & $\begin{array}{l}\text { Permanent process of identification of signs of the crisis phe- } \\
\text { nomena and implementation of the master plan of prevention of } \\
\text { distribution of the crisis phenomena and stagnation of develop- } \\
\text { ment of the enterprise is carried out during the entire period of } \\
\text { his functioning. }\end{array}$ \\
\hline Vasilenko V.O. & $\begin{array}{l}\text { The management referred on predictions of danger of crisis, } \\
\text { the analysis of its symptoms and elimination of threats of emer- } \\
\text { gence of crisis situations, and in case of their emergence - the } \\
\text { analysis and acceptance the fast of measures of liquidating char- } \\
\text { acter with the smallest losses and negative consequences. }\end{array}$ \\
\hline $\begin{array}{l}\text { Keins Dj., } \\
\text { Kujel V.V. }\end{array}$ & $\begin{array}{l}\text { System of the measures from the state for providing restoration } \\
\text { and stabilization of development of economic system. }\end{array}$ \\
\hline $\begin{array}{l}\text { Damb. A., } \\
\text { Koshkin A., } \\
\text { Kryukova I. }\end{array}$ & $\begin{array}{l}\text { Anti-recessionary regulation is considered as the mechanism of } \\
\text { avoidance of bankruptcy and improvement of a financial condi- } \\
\text { tion of the enterprise. }\end{array}$ \\
\hline $\begin{array}{l}\text { Balashov A., } \\
\text { Ilin S. }\end{array}$ & $\begin{array}{l}\text { Crisis management - system of actions for restoration of sol- } \\
\text { vency of the enterprise. }\end{array}$ \\
\hline Bondar-Pidgirska O.V. & $\begin{array}{l}\text { Crisis management through creative activity of the enterprise } \\
\text { for the prevention of the crisis phenomena and recovery from } \\
\text { the crisis if the enterprise has already got into a crisis. }\end{array}$ \\
\hline Mahovka V. & $\begin{array}{l}\text { Crisis management as specific function has to be implemented } \\
\text { through performance of anti-recessionary actions, the ways } \\
\text { directed to the prevention, overcoming the crisis phenomena, } \\
\text { improvement of economic activity and restoration of stable } \\
\text { development of the enterprise, interacting with other main } \\
\text { functions of management; as process consists in interrelation } \\
\text { of all administrative activity directed to preparation and real- } \\
\text { ization of crisis response solutions on restoration and stabi- } \\
\text { lization of functioning of the enterprise in the conditions of } \\
\text { crisis; as the structure consists in definition of management } \\
\text { rules by the enterprise, allows defining hierarchy of levels } \\
\text { of management and communication between them, the level } \\
\text { of centralization and decentralization in the course of dis- } \\
\text { tribution of functions, powers, duties and responsibility of } \\
\text { employees of the enterprise of all levels during realization of } \\
\text { the actions directed to overcoming crisis; as the qualified and } \\
\text { professional administrative people having the corresponding } \\
\text { vocational training which main task is implementation of con- } \\
\text { tinuous monitoring of a condition of subsystems of the enter- } \\
\text { prise, early identification of signs of crisis and prevention of } \\
\text { her expansion (expeditious localization), holding preventive } \\
\text { improving actions. }\end{array}$ \\
\hline
\end{tabular}




\begin{tabular}{|c|c|}
\hline & Continuation of Table \\
\hline $\begin{array}{l}\text { Korotkov E., } \\
\text { Kotenko I. }\end{array}$ & $\begin{array}{l}\text { Management where it is properly adjusted crisis predictions, the } \\
\text { analysis of its symptoms, measures for minimization of nega- } \\
\text { tive impact and use of positive factors for further development } \\
\text { of the enterprise. }\end{array}$ \\
\hline $\begin{array}{l}\text { Bilovol R., } \\
\text { Ligonenko L., } \\
\text { Tereschenko O. }\end{array}$ & $\begin{array}{l}\text { Crisis management is considered as a part of the general system } \\
\text { of management at the enterprise at emergence of a crisis. }\end{array}$ \\
\hline Gryaznova A.G. & $\begin{array}{l}\text { It is such control system which has complex character and it is } \\
\text { directed to prevention or elimination of the phenomena, undesir- } \\
\text { able to business, by use of all potential of modern management, } \\
\text { development and realization at the enterprise of the special pro- } \\
\text { gram having strategic character and allows liquidating temporary } \\
\text { complications, to keep and increase market positions under any } \\
\text { circumstances, when using generally own resources. }\end{array}$ \\
\hline Ligonenko L. O. & $\begin{array}{l}\text { It is a part of management of the enterprise in general that rep- } \\
\text { resents the special, constantly organized management for the } \\
\text { most quick identification of signs of crisis state and creation of } \\
\text { the corresponding prerequisites for his timely overcoming for } \\
\text { ensuring restoration of viability of the separate enterprise, pre- } \\
\text { vention of emergence of a situation of his bankruptcy. }\end{array}$ \\
\hline Keller R. & $\begin{array}{l}\text { It is the special form of government which priority task is the } \\
\text { prevention or overcoming all processes which are capable to } \\
\text { create essential threat for activity of the enterprise or even to } \\
\text { exclude his functioning. }\end{array}$ \\
\hline Pokritan P. A. & $\begin{array}{l}\text { Is engaged in studying of system of the economic relations con- } \\
\text { nected with emergence of the crisis phenomena in the course of } \\
\text { functioning of subjects of economy. }\end{array}$ \\
\hline $\begin{array}{l}\text { Belyaev S., } \\
\text { Koshkin V. I. }\end{array}$ & $\begin{array}{l}\text { Makes set of forms and methods of implementation of anti-re- } \\
\text { cessionary ways according to the concrete enterprise debtor. }\end{array}$ \\
\hline $\begin{array}{l}\text { Minaev E. S., } \\
\text { Panagushin V. P. }\end{array}$ & $\begin{array}{l}\text { It is necessary to understand as crisis management not only the } \\
\text { management focused on a conclusion of the enterprise from } \\
\text { a condition of crisis, but also management which in advance } \\
\text { to predict and prevent insolvency according to the developed } \\
\text { program of increase in competitive advantages and financial } \\
\text { improvement. }\end{array}$ \\
\hline Utkin E. A. & $\begin{array}{l}\text { This management directed to the prevention of possible heavy } \\
\text { complications in market activity of the enterprise, ensuring his } \\
\text { stable, successful managing with orientation to expanded resto- } \\
\text { ration omit and own savings. }\end{array}$ \\
\hline $\begin{array}{l}\text { Burii S. A., } \\
\text { Maceha D. S. }\end{array}$ & $\begin{array}{l}\text { Crisis management is a system of constant system actions of the } \\
\text { managers directed to all elements of the organization for quick } \\
\text { and prompt response to possible external and internal threats at } \\
\text { effective functioning or development of the organization. }\end{array}$ \\
\hline
\end{tabular}


The main theoretical aspects of system of crisis management at the...

Ending of Table

\begin{tabular}{|l|l|}
\hline Shpachuk V. V. & $\begin{array}{l}\text { The administrative system based on the strategic principles is also } \\
\text { directed to maintenance of a steady, stable condition of any social } \\
\text { and economic system during the entire period of her functioning, } \\
\text { has complex character, is capable to adapt and change quickly } \\
\text { depending on external conditions, the environment. }\end{array}$ \\
\hline Dovgan D. A. & $\begin{array}{l}\text { Effective management gives the chance to bring firm out of cri- } \\
\text { sis, set of the actions directed to achievement or restoration of } \\
\text { solvency, liquidity, profitability and competitiveness of firm and } \\
\text { capable to lead firms to financial improvement. }\end{array}$ \\
\hline Blank I.O. & $\begin{array}{l}\text { System of the principles and methods of development and } \\
\text { implementation of the special administrative decisions directed } \\
\text { to the prevention and overcoming financial crises of the enter- } \\
\text { prise, and minimization of their negative consequences. }\end{array}$ \\
\hline Sitnik L.V. & $\begin{array}{l}\text { It is ability to develop best ways of an exit from a crisis, to decide } \\
\text { priority values of the enterprise in the conditions of crisis, to coor- } \\
\text { dinate activities of firm and its workers for crisis anticipation, to } \\
\text { try to get efficiency of their work in extreme conditions. }\end{array}$ \\
\hline
\end{tabular}

As we see, all definitions of this concept take place and at the current development of economy, and, having grouped them, it is possible to note that today crisis management by the subject of any business is used as for the prevention of development of the enterprise of crisis situations, and for control system adaptation to changes in external market environment of firm that will allow firm not to lose the positions in that segment of the market in which it functions. Because of it in firms it is necessary to create system of crisis management, will allow controlling the crisis phenomena, to carry out planning, the organization and realization of crisis response measures for effective functioning of the enterprise.

\section{The main making systems of crisis management}

Subject of crisis management are predictable and real reasons of crisis state of the enterprise, factors, the causing crises, consequences which involve crisis, which is all this what leads to equilibrium disturbance that causes threat of offensive and development of crisis. Main goal of crisis management - providing a stable financial position of business thanks to well-timed response to the changes caused by the external environment (it can be economic, social, political, demographic, international changes, etc.) by means of enforcement of anti-recessionary tools which will give well-timed elimination of financial complications in firm and will provide 
prevention of symptoms of bankruptcy on it. On the basis of researches of works of outstanding scientists-economists we will divide the main groups of the purposes of crisis management by the enterprise. The financial, staff, production, marketing and organizational purposes belong to such purposes.

The financial group of the purposes understands as itself rising of level of solvency of the subject of business, body height and prevention of reduction of the liquidity, and also minimization of consequences of financial crisis. The personnel purposes become clear of the name of group of the purpose. The main objectives of these purposes are depression of a current of staff and prevention of emergence of various crises through various negative factors (psychological, social, demographic, indifference, etc.). The staff purposes as the group of the purposes of crisis management at the enterprise is a depression of level of marriage of the made goods and the rendered services, preventions of obsolescence of the equipment, introduction of a know-how on production for the purpose of improvement of production and reduction of expenses, adjustment of the organization of production without the compelled stoppings. The marketing group of the purposes is that series for the enterprise, referred on definition of symptoms of crisis of activity of sale. Here it is possible to carry prevention of decrease of customers of goods, prevention of decline in quality of production in comparison with competitor companies, the analysis of the prices of similar goods, continuous monitoring of quality and costs of goods of the leading firms on certain segments of the market.

On the basis of research the formulated purposes of the enterprise it is possible to divide the following key tasks of crisis management of the subject of business:

1. Research of the external environment and internal activity of the subject of business and choice of strategy of his development on the basis of the forecast of a financial condition of the enterprise; 2. A research of the causes of the crisis phenomena in a certain segment of functioning of firm and in the enterprise; 3. Planning of an exit of the enterprise from a crisis; 4. Prevention of a current of skilled workers from the enterprise, constant improvement of activity of staff for improvement of indicators of activity of the enterprise at all stages of his activity; 5. Implementation of ways of crisis management of the enterprise and control of their unconditional performance. 6 . Introduction of the anti-recessionary program at the enterprise and control of her performance; 7. Analysis of results of introduction of 
the anti-recessionary program; 8. Implementation of continuous monitoring further with an opportunity to avoid crisis situations.

On the basis of researches of a number of works on crisis management of subjects of business it is possible to define the main methods of crisis management which can be divided on tactical and strategic. To tactical methods of crisis management of the enterprise it is possible to carry: diagnostics; monitoring; outsourcing; benchmarking; dutting; repolarization; controlling; audit of business processes; restructuring. Treat strategic methods: sanitation (external and internal) bankruptcy; merges; diversification; reengineering.

\begin{tabular}{|c|l|}
\hline $\begin{array}{c}\text { Method } \\
\text { of crisis } \\
\text { management }\end{array}$ & Essence and application \\
\hline Tactical methods & $\begin{array}{l}\text { Crisis can strike any of subsystems of the enterprise, and it means } \\
\text { that process of overcoming the crisis phenomena has to offer system } \\
\text { vision of all processes of development of anti-recessionary actions } \\
\text { and management of them. It is expedient to consider diagnostics as a } \\
\text { complex method of crisis management which will include the analy- } \\
\text { sis of activity of the enterprise in general, namely: situation, financial } \\
\text { and economic, organizational and administrative, production and eco- } \\
\text { nomic analyses. It should be noted that complex diagnostics will allow } \\
\text { revealing the problems caused by crisis, their reasons, the center and } \\
\text { to define the direction of crisis response measures which have to be } \\
\text { realized within restoration of a pre-crisis condition of the enterprise, or } \\
\text { improvement of management and functioning of the enterprise }\end{array}$ \\
\hline Monitoring & $\begin{array}{l}\text { The system of monitoring of crisis represents specially organized } \\
\text { actions for determination of chance and real possibility of a crisis } \\
\text { situation and is necessary for her timely identification. }\end{array}$ \\
\hline \multirow{5}{*}{ Outsourcing } & $\begin{array}{l}\text { The major reason of modern business caused by sharp changes of the } \\
\text { used technologies; optimization of activity and reduction of expenses } \\
\text { of the enterprise or organization on the basis of concentration on the } \\
\text { main fields of activity and transfers of secondary or non-core func- } \\
\text { tions to third-party performers. Outsourcing use as method of crisis } \\
\text { management will give the chance to the enterprise which is in crisis } \\
\text { state, to concentrate attention and the available resources on over- } \\
\text { coming the problems caused by crisis ensuring implementation of } \\
\text { primary activity and will allow transferring some risks to the com- } \\
\text { panies outsourcers, to increase controllability the enterprise in the } \\
\text { conditions of crisis, to improve organizational structure, to cut costs } \\
\text { of service and business processes and to increase profit. }\end{array}$ \\
\hline
\end{tabular}




\begin{tabular}{|c|c|}
\hline & Continuation of Table \\
\hline Benchmark & $\begin{array}{l}\text { The instrument of management, uses comparisons of data own and } \\
\text { the enterprises competing with him taking the advanced positions in } \\
\text { a certain segment of economy and allocation and introduction of the } \\
\text { best the practicing for development of own enterprise }\end{array}$ \\
\hline Dutting & $\begin{array}{l}\text { Reduction of production capacities and the number of production and } \\
\text { administrative staff of the enterprise according to real demand and } \\
\text { market opportunities. Use of this method leads to much reduction of } \\
\text { constant expenses, reduction of product cost. }\end{array}$ \\
\hline Regularization & $\begin{array}{l}\text { Introduction of modern approaches to business management. Treat } \\
\text { such approaches: formation of system of strategic planning and man- } \\
\text { agement accounting, creation of complex system of financial control } \\
\text { and planning, the automated system of the account, full-fledged mar- } \\
\text { keting services and so forth. By means of this method the enterprises } \\
\text { form the control systems capable to solve large volume of the complex } \\
\text { problems connected with work in market conditions, an exit to inter- } \\
\text { national markets. New control systems allow aiming resources of the } \\
\text { enterprises at the further stable development. }\end{array}$ \\
\hline Controlling & $\begin{array}{l}\text { Rather effective by method of crisis management it is possible to call } \\
\text { controlling that represents synthesis of continuous monitoring of sig- } \\
\text { nificant changes, control, the economic analysis and diagnostics of a } \\
\text { financial state, planning, the organization of information streams for } \\
\text { adoption of administrative decisions that will allow predicting most } \\
\text { fully future crisis situations and to exercise effective crisis manage- } \\
\text { ment by the enterprise. Application of controlling in anti-recession- } \\
\text { ary managements will allow carrying out, first, information support } \\
\text { of decision-making for best use of the available opportunities and } \\
\text { resources, an appropriate assessment positive and the negative enter- } \\
\text { prises of activity, and prevention and avoidance of bankruptcy and cri- } \\
\text { sis situations; secondly, to increase the speed of reaction of managers } \\
\text { to changes of external and internal environment, to increase flexibil- } \\
\text { ity of the enterprise, to pass on control of the past to the analysis and } \\
\text { forecasting of the future. The set of works on studying of activity of } \\
\text { the enterprise directed to obtaining information on current state of his } \\
\text { affairs, to check of compliance of the operating business processes to } \\
\text { the requirements to business processes established in normative and } \\
\text { organizational and administrative documents of this enterprise, and } \\
\text { also carrying out the analysis and an assessment of efficiency busi- } \\
\text { ness - processes on certain indicators. Use of these methods in crisis } \\
\text { management to promote high-quality improvement of characteristics } \\
\text { of activity of the enterprise and acceptance to his fast getting out of } \\
\text { crisis state Implementation of the organizational and economic, legal, } \\
\text { technological actions directed to change of structure of the enterprise, } \\
\text { his management, managing forms which can offer to the enterprise } \\
\text { financial improvement, increase in volumes of release of competitive } \\
\text { production, increase in production efficiency. }\end{array}$ \\
\hline
\end{tabular}




\begin{tabular}{|c|c|}
\hline & Ending of Table \\
\hline Controlling & $\begin{array}{l}\text { It is expedient to apply at early stages of life cycle of the enterprise } \\
\text { and when crisis is inevitable, however at this stage restructuring takes } \\
\text { place more difficult. It is carried out for the purpose of overcoming } \\
\text { the reasons of strategic crisis and crisis of profitability. }\end{array}$ \\
\hline $\begin{array}{l}\text { Audit of busi- } \\
\text { ness processes }\end{array}$ & $\begin{array}{l}\text { The set of works on studying of activity of the enterprise directed to } \\
\text { obtaining information on current state of his affairs, to check of com- } \\
\text { pliance of the operating business processes to the requirements to busi- } \\
\text { ness processes established in normative and organizational and admin- } \\
\text { istrative documents of this enterprise, and carrying out the analysis and } \\
\text { an assessment of efficiency business - processes on certain indicators. }\end{array}$ \\
\hline Restructuring & $\begin{array}{l}\text { Implementation of the organizational and economic, legal, tech- } \\
\text { nological actions directed to change of structure of the enterprise, } \\
\text { his management, managing forms which can offer to the enterprise } \\
\text { financial improvement, increase in volumes of release of competitive } \\
\text { production, increase in production efficiency. It is expedient to apply } \\
\text { at early stages of life cycle of the enterprise and when crisis is inevi- } \\
\text { table, however at this stage restructuring takes place more difficult. It } \\
\text { is carried out for the purpose of overcoming the reasons of strategic } \\
\text { crisis and crisis of profitability. }\end{array}$ \\
\hline & \\
\hline $\begin{array}{l}\text { Sanitation: } \\
\text { - external } \\
\text { - interior }\end{array}$ & $\begin{array}{l}\text { System of the financial and economic, technological, organizational } \\
\text { and legal and social actions directed to achievement of solvency, } \\
\text { liquidity, profitability and competitiveness of the enterprise of the } \\
\text { debtor in long-term period. It is applied at emergence of threat of } \\
\text { bankruptcy; } \\
\text { Set of all possible actions which are capable to lead the enterprise to } \\
\text { financial improvement at the cost of own sources. } \\
\text { It is applied at bankruptcy threat emergence. }\end{array}$ \\
\hline Bankruptcy & $\begin{array}{l}\text { The inability of the debtor recognized by economic court to restore } \\
\text { the solvency and to meet the requirements of creditors recognized } \\
\text { by court precisely through application of the liquidating procedure. }\end{array}$ \\
\hline Merger & $\begin{array}{l}\text { Association within one organization of various stages of produc- } \\
\text { tion and distribution, different types of activity. Application of this } \\
\text { method becomes expedient when such integration leads to essential } \\
\text { economy at a scale or to much reduction of transaction expenses. }\end{array}$ \\
\hline Diversification & $\begin{array}{l}\text { Expansion of a field of activity of the enterprise in any direction not } \\
\text { to be dependent on one market. It is applied at the beginning of cre- } \\
\text { ation of the enterprise and at the first signs of crisis. }\end{array}$ \\
\hline Reengineering & $\begin{array}{l}\text { Consists in a redesign of business processes of the enterprise. Due } \\
\text { to reduction of excess links and operations in business processes, } \\
\text { excess expenses of time and other resources, reengineering allows } \\
\text { reaching sharp, spasmodic increase in indicators efficiency of activ- } \\
\text { ity, such as labor productivity, holding time or production of produc- } \\
\text { tion, prime cost and so forth. }\end{array}$ \\
\hline
\end{tabular}




\section{Indicators of efficiency of use of crisis management by the enterprise}

Success of crisis management of the enterprise directly depends on performance of certain functions. Functions of crisis management - it is separated from each other the directions of administrative activity which essence consists in prevention of emergence of anti-recessionary actions. If to pass to a specification of definition of the main functions of crisis management, then note that all of them are set of certain actions and operations which aim at anti-recessionary character and which are carried out for coordination of the main actions of firm at an exit from a crisis. Having carried out the detailed analysis of works of outstanding economists we will allocate the main functions of crisis management: planning, organization, motivation and control. It can be explained with the fact that it is rational to investigate crisis management of the subject of any business as one of the functional directions of management of firm and to define him as the process of planning, the organization, motivation and control necessary for formation and achievement of the tasks defined before the enterprise. By definition of efficiency of crisis management by the enterprise and factors, it defining that should be noted that the matter was subject slightest to research though becomes clear that determination of such key categories as result, efficiency indicators, effect are key questions in formation of a control system of any subject "object of business. The research of problems of efficiency and the main approaches to an assessment of efficiency was subject to studying by many famous scientists-economists that has given the soil for formation of several directions of determination of these categories and formation of estimated indicators of efficiency of crisis management of the enterprise.

Now the following types of efficiency are created: 1 . Depending on the achieved results - economic which in the general sense means a ratio of the achieved results and the spent materials necessary for their achievement and, also, social efficiency which considers social indicators (improvement of working conditions, healthy psychological climate in the enterprise, preservation of jobs, etc.); 2. Depending on the place of obtaining effect - shares on economic, belonging to society or commercial effectiveness which can be, also, divided into efficiency of firm, efficiency of division (department, service), efficiency of separate operation, etc.; 3. Depending on a calculation method - absolute efficiency that gives the general or specific the characteristic of efficiency of activity of the subject of business for the certain 
period, and comparative efficiency defining results of comparison of alternative options and the choice of the best of them; 4 . Depending on approach to an assessment - partial, indicative and full efficiency; 5. Depending on an assessment object - it can be production efficiency, efficiency of use of labor, material and financial resources, efficiency of the organization of any administrative process of activity, system effectiveness of management of firm; 6. Depending on extent of increase effects - is divided into primary (first) efficiency, animated and work together efficiency. We will pass to more complete definition of above-mentioned types of efficiency: Primary efficiency - is disposable effect which is defined at the initial stage thanks to realization of certain actions (technological, economic, social, organizational, technical, etc.).

Animated efficiency is a result of repeated use of innovations not only at subjects of business, but also in other fields of activity. Animated efficiency lights the activity in the following forms:

1. Effect of "starting explosion" that in essence means a geometrical progression of increase in effect under the influence of primary impulse; 2 . The resonant effect is an effect which arises with activation and stimulation of development of the positive phenomena both on own, and in competitor companies (spheres of economy); 3. The effect of acceleration is an effect which in essence characterizes acceleration of rates of distribution of a certain positive result; 4 . The effect of accompanying opportunities - this effect is shown in a section of intermediate and side positive effects; 5 . The diffusion effect is an effect which can be received by means of the greatest distribution to other spheres of activity. Synergy efficiency represents cumulative influence of all innovations on a financial and economic condition of the enterprise exceeds the arithmetic sums of the effects gained from all executed actions.

After we to define the main components of crisis management by the enterprise, we will try to define the main criteria by which it is possible to define efficiency of crisis management by the subject of business: 1 . Changes to the best key indicators of financial and economic activity in general and a financial condition of the company in general during definition of crisis and performance of the main actions for her elimination; 2. A gain of the main indicators of financial and economic activity for a certain time period (week, month, quarter, decade, etc.); 3. Definition of profitability of obtaining result, which is an assessment of a ratio of the achieved results of financial and economic activity of the enterprise to the volume of all expenses 
necessary for an exit from an anti-recessionary situation; 4. The analysis of the reached indicators with those which have been defined for achievement by firm for the purpose of an exit from a crisis and studying of results with the next conclusion about sufficiency of changes for restoration of activity of firm. These criteria allow defining the main indicators of efficiency of crisis management by the enterprise by means of which it will be possible to estimate all system of crisis management by the enterprise.

\section{Conclusions}

Expediency and efficiency of crisis management by the enterprise it is caused by the general influence of the following factors: 1. Professionalism and enough vocational training, and personal qualities of the subject of crisis management; 2 . A possibility of formation of the anti-recessionary team capable to carry out the tasks set for her in the conditions of crisis ; 3. Support of managers of the company who are responsible for efficiency of her activity by workers and owners of the company, enthusiasm and ability of all to work as a unit with the exit purpose from crisis situations which have arisen before the enterprise; 4 . Development of administrative decisions which will allow overcoming the crisis phenomena; 5. Validity of carrying out receptions and analytic researches which take place at all stages of implementation of crisis management by the enterprise; 6 . Sufficient efficiency of crisis management by the enterprise during implementation of anti-recessionary actions; 7. Existence at the enterprise of programs which will allow carrying out holding diagnostic and predictive rules and researches for definition of the best options for creation of effective system of crisis management. Having considered the making systems of crisis management becomes obvious that activity of all subjects of business has to be directed to crisis management. Process of an exit of firm of a crisis situation it has to be carried out not chaotically, and it is consecutive according to all above-mentioned stages of carrying out crisis management at the enterprise. Each enterprise has to carry out constantly monitoring as on a certain segment of the market where it conducts the direct activity, and to carry out introspection for the purpose of prevention of emergence of the crisis phenomena. But at this stage of development of economy for the domestic enterprises such method of crisis management as a benchmark will be the best. For this reason the administrative board of any enterprise has to realize a role of system of crisis management at the enterprise as constantly existing subsystem. 


\section{References:}

1. Barinov V. A. Crisis management: studies. Grant, Moscow: IDES FBK Press, $488 \mathrm{p}$.

2. Bondar Pidgurska O. V. (2013) Innovative activity of the industry in the conditions of global crisis. Technological audit and reserves of production. Kharkiv. № 2/2 (10), p. 18-22.

3. Vasilenko V. O. (2003) Crisis management by the enterprise: Studies. grant, Kiev: TsUL, 2003, p. 289-299.

4. Mahovka V. M. (2013) Methodology of formation of system of crisis management by the enterprise, All-Ukrainian scientific and practical magazine Innovative economy, No. 1 (39), p. 102-105.

5. Mahovka V. M. (2012) Process, methods and functions of crisis management at the enterprise. Scientific bulletin of the Poltava university of economy and trade, No. 1 (52), p. 219-225.

6. Mihova A. V. (2009) Crisis management by personnel a condition of effective functioning of the company during crisis. Retrieved from: http://www.confcontact.com/2009_03_18/ek6_mihova.php

7. Sheremet O. O. (2005) Financial analysis: Manual, Kiev, p. 117-120.

8. Yakovleva Yu. S. (2006) Assessment of financial stability of the enterprise for criterion of indicators of stability, Finance of Ukraine, No. 5, p. 29-31. 